\title{
Polish Theriological Bibliography, 1984
}

Polska Bibliografia Teriologiczna. 1984

Польская Териологическая Библиография, 1984

\section{Michalina PUCEK}

I. List of periodical titles and their abbreviations . . . . . . 505

II. Titles of papers not included in previous issues for $1982-1983 . \quad 506$

III. Titles of papers published in 1984 . . . . . . . . . 510

IV. Subject index . . . . . . . . . . . . . . . . 510

0 . General literature

1. Evolution and Genetics

2. Morphology

3. Physiology

4. Reproduction, Sex, Hybridisation

5. Development

6. Ecology, Biology and Conservancy

7. Distribution, Fauna and Systematics, Palaeontology

8. Parasites, Epidemiology and Pathology

\section{LIST OF PERIODICAL TITLES AND THEIR ABBREVIATIONS}

Acta agrar. silvestr., Silvestr.

Acta parasit. pol.

Acta theriol.

Acta zool. cracov.

Acta Zool. Fennica

Annls Univ. M. Curie-Skłodowska, C

Annls Univ. M. Curie-Skłodowska, D

Annls Univ. M. Curie-Skłodowska, DD

Ann. Wars. Agricult. Univ. - SGGW-AR, Vet. Med.

Archs Anat. microsc. Morph. exp.

Bat Res. News

Beitr. Jagd-u. Wildforsch.

Biochem. genet.

Bull. Acad. pol. Sci., Cl. II

Bull. Pol. Acad. Sci., Biol. Sci.

Chrońmy Przyr. ojcz.

Comp. Biochem. Physiol. A
- Acta Agraria et Silvestria, Series Si vestris, Kraków

- Acta Parasitologica Polonica, Warsza. wa

- Acta Theriologica, Białowieża - Warszawa

- Acta Zoologica Cracoviensia, Kraków

- Acta Zoologica Fennica, Helsinki

- Annales Universitatis Mariae Curie-Skłodowska, Sectio C, Biologia, Lublin

- Annales Universitatis Mariae Curie-Skłodowska, Sectio D, Medicina, Lublin

- Annales Universitatis Mariae Curie-Skłodowska, Sectio DD, Medicina Veterinaria, Lublin

Annals of Warsaw Agricultural University SGGW -AR, Veterinary Medicine. Warszawa

- Archives d'Anatomie Microscopique et de Morphologié Expérimentale, Paris

- Bat Research News, Potsdam, N. Y.

- Beiträge zur Jagd- und Wildforschung, Berlin

- Biochemical Genetics, New York

- Bulletin de l'Ácadémie Polonaise des Sciences, Classe II, Série des Sciences Biologiques, Varsovie

- Bulletin of the Polish Academy of Sciences, Biological Sciences, Warsaw

- Chronmy Przyrode Ojczystą, Kraków

- Comparative Biochemistry and Phy[505] siology, A Physiology, Oxford 
Deer

Folia biol.

Folia morph.

Immunogenet.

J. Hirnforsch.

Łowiec pol.

Med. wet.

Ossa

Palaeont. pol.

Palaeovert.

PWN

PWRiL

Parki nar. Rez. Przyr.

Pol. ecol. Stud.

Pol. Archwm wet.

Pr. mat. zootechn.

Prz. zool.

Roczn. Akad. roln. Poznań, zootechn.

Spraw. Pos. Kom. nauk. Pol. Akad. Nauk

Studia Nat., B

Sylwan

Wiad. parazyt.

Wierchy

Wszechśw.

Z. Geol, Wiss.

Z. Säugetierk.

Z. Tierzìichtg. Züchtgsbiol.

Zesz. nauk. ART Olszt., wet.

Zool. Pol.

Zool. J. Linn. Soc. Lond.

Zool. Abh. Mus. Tierk. Dresden

\section{Zool. Anz.}

Zwierzęta Lab.
- Deer, Journal of the British Deer So. ciety, Southampton

- Folia Biologica, Kraków

- Folia Morphologica, Warszawa

- Immunogenetics, Berlin

- Journal für Hirnforschung, Berlin

- Łowiec Polski, Warszawa

- Medycyna Weterynaryjna, Lublin

- Ossa, Lund

- Palaeontologia Polonica, Warszawa

- Palaeovertebrata, Montpellier

- Państwowe Wydawnictwo Naukowe.

Warszawa

- Państwowe Wydawnictwo Rolne i Leśne, Warszawa

- Parki Narodowe i Rezerwaty Przyrody, Warszawa

- Polish Ecological Studies, Warszawa

- Polskie Archiwum Weterynaryjne. Warszawa

- Prace i Materialy Zootechniczne, Warszawa

- Przegląd Zoologiczny, Wrocław

- Roczniki Akademii Rolniczej w Poznaniu, Wydzial Zootechniczny, Poznań

- Sprawozdania z Posiedzeń Komisji Naukowych. Polska Akademia Nauk. Oddzial w Krakowie, Kraków

- Studia Naturae, Seria B, Wydawnictwa Popularno-Naukowe, Warszawa. Kraków

- Sylwan, Warszawa

- Wiadomości Parazytologiczne, Wrocław

- Wierchy, Kraków

- Wszechświat. Kraków

- Zeitschrift für Geologische Wissenschaften, Berlin

- Zeitschrift für Säugetierkunde, Hamburg

- Zeitschrift für Tierzüchtung und Züchtungsbiologie, Berlin, Hamburo

- Zeszyty Naukowe Akademii Rolniczo -Technicznej w Olsztynie, Weteryna ria, Olsztyn

- Zoologica Poloniae, Wrocław

- 7oolooical Tournal of the Linnaean Society, London

- Zoologische Abhandlungen Staatlinhes Museum für Tierkunde Dresden Dresden

- Zoologischer Anzeiger. Leipzig

- Zwierzeta Laboratoryjne. Warszawa

- książki, books,

II. TITLES OF PAPERS NOT INCLUDED IN PREVIOUS ISSUES FOR 1982--1983

1982

GORECKI A. (1), see WEINER J. \& GORECKI A.

GORECKI A. (2), see WEINER J, et al, 
GORECKI A. (3), see WEINER J. et al.

GORECKI A., WEINER J. \& ZEMANEK M. [Dept. Anim. Ecol., Jagiell. Univ., Karasia 6, 30-060 Kraków]: Food composition and nutritional balance in two species of Mongolian small mammals. Pol. ecol. Stud., 8, 1-2: $57-67$ [Polish and Russ. summ.].

GRODZIŃSKI W., see WEINER J. et al.

- KIELAN-JAWOROWSKA M. [Palaeobiol. Inst., P. A. Sci., Zwirki i Wigury 93, 02-089 Warszawa]: Marsupial-placental dichotomy and paleogeography of Cretaceous Theria. In "Palaeontology, Essential of Historical Geology". Proc. Intern. Meet.ng, Verice, 2-4 June 1981, Ed. E. Montanaro-Galitelli, S. T. E. M. Mucchi Modena Press: $367-383$.

- KUBIAK H. (1) [Inst. Syst. \& Exp. Zool., P. A. Sci., Sławkowska 17, 31-016 Kraków]: Morphological characters of the mammoth: an adaptation to the Arctic-Steppe environment. In "Palaeoecology of Beringia", Eds D. M. Hopkins, J. V. Matthews Jr., Ch. E. Schweger. S. B. Young, Academic Press, Inc., New York: $281-289$.

KUBIAK H. (2): [The Miocene finds of vertebrates from Przeworno (Lower Silesia, Poland)]. Z. Geol. Wiss., 10, 7: 997-1007 [In German].

PERZANOWSKI K., see WEINER J. et al.

PIELOWSKI Z. [Polish Hunting Assoc., Res. St., 64-020 Czempiń n/Poznań]: Importance of fox in hunting. Beitr. Jagd-u. Wildforschung 12: 71-77 [In German with English and Russ. summ.].

- PUCEK Z. [Mammals Res. Inst., P. A. Sci., 17-230 Białowieża]: Familie Zapodidae Coues, 1875 - Hüpfmäuse. In „Handbuch der Säugetiere Europas”, Eds J. Niethammer \& F. Krapp, Akad. Verlagsgesel., Wiesbaden, Bd 2/I: 497-538.

SZYMURA J. M. \& KLEIN J. [Dept. Comp. Anat., Jagiell. Univ., Karasia 6, 30-060 Kraków]: Mapping of the mouse Upg-1. Immunogenet., 16: 89-90.

SZYMURA J. M., TAYLOR B. A. \& KLEIN J.: Upg-2: a urinary pepsinogen variant located on chromosome 1 of the mouse. Biochem. Genet., 20, 11-12: 1211-1219 .

SMIEEOWSKI J. [Inst. Appl. Zool., Agric. Acad., Al. Wojska Polskiego 71c, 60-625 Poznańl: Rozmnazanie i przeżywalność bizona, Bison bison (Linnaeus, 1758) w warunkach Zoo - Breeding and survival of plains bison, Bison bison (Linnaeus, 1758 ) in the Zoo environment. Roczn. Akad. roln. Poznań, 139, Zootechn. 30: 213-223 [In Polish with English and Russ. summ.].

TOMEK A. \& ZYGAROWICZ F. [Inst. Forest Protect., Agric. Acad., Czysta 21/6, 31-121 Kraków]: Badania rozmiaru i charakteru spałowania powodowanego przez jelenie $w$ drzewostanach górskich na przykładzie wybranego kompleksu w Leśnym Zakładzie Doświadczalnym w Krynicy - A study on the extent and character of debarking done by red deer in mountain tree stands at a forestry experimental station in Krynica, Poland. Acta agrar. silvestr., Silvestr. 21: 121-132 [In Polish with English and Russ. summ.].

WEINER J., see GORECKI A. et al.

WEINER J. \& GORECKI A. [Dept. Anim. Ecol., Jagiell. Univ., Karasia 6, 30-060 Kraków]: Small mammals and their habitats in the arid steppe of central eastern Mongolia. Pol. ecol. Stud., 8, 1-2: $7-21$ [Polish and Russ. summ.].

WEINER J., GORECKI A. \& ZIELINSSKI J.: The effect of rodents on the rate of matter and energy cycling in ecosystem of arid steppe of central eastern Mongolia. Pol. ezol. Stud., 8, 1-2: $69-86$ [Polish and Russ. summ.].

WEINER J. GRODZIŃSKI W., GORECKI A. \& PERZANOWSKI K.: Standing crop and above-ground production in arid Mongolian steppe with Caragana. Pol. ecol. Stud., 8, 1-2: 23-39 [Polish and Russ. summ.].

ZEMANEK M., see GORECKI A. et al.

ZIELIN̂SKI J. (1) [Dept. Anim. Ecol., Jagiell. Univ., Karasia 6, 30-060 Kraków]: The effect of Brandt vole (Microtus brandti Radde, 1861) colonies upon vege- 
tation in the Caragana steppe of central eastern Mongolia. Pol. ecol. Stud., 8, 1-2: 41-56 [Polish and Russ. summ.].

ZIELINSKI J. (2), see WEINER J. et al.

ZYGAROWICZ F., see TOMEK A. \& ZYGAROWICZ F.

\section{3}

ADAMCZYK K., see WALKOWA W. et al.

BIAEOWĄS J., see NITECKA L. et al.

- BOCHENSSKI Z. [Inst. Syst. \& Exp. Zool., P. A. Sci., Sławkowska 17, 31-016 Kraków]: Swiat zwierzęcy Babiej Góry. Kręgowce - [Animal world of the Babia Góra National Park. Vertebrates]. In "Park Narodowy na Babiej Górze Człowiek i Przyroda", Ed. K. Zabierowski, Studia Nat. B, 29: 211-227 [In Polish].

BUGAJAK P., see ROMANIUK K. et al.

CHEŁKOWSKA K., see WALKOWA W. et al.

FLIEGER S., see STRZAEKA B. \& FLIEGER S.

GASIENICA-BYRCYN W. [Tatra Nat. Park, 34-500 Zakopane]: O rogach kozicy - [On the chamois horns]. Wierchy, 50(1981): 315-317 [In Polish].

- KA£WA S. \& TOMEK A. [Inst. Forest Protect., Agric., Acad., Czysta 21/6, 31-121 Kraków]: Zagadnienia lowieckie w rejonie Babiej Góry - [Wildlife management in the region of Babia Góra National Park]. In "Park Narodowy na Babiej Górze - Przyroda i Człowiek", Ed. K. Zabierowski, Studia Nat. B, 29: 347-257 [In Polish].

KIELAN-JAWOROWSKA Z. [Palaeobiol. Inst., P. A. Sci., Zwirki i Wigury 93, 02-089 Warszawa]: Multituberculate endocranial casts. Palaeovert., 13, 1-2: $1-12$. KOBRYNCZUK F., see ROSKOSZ T. \& KOBRYNCZUK F.

KRZANOWSKI A. [Inst. Syst. \& Exp. Zool., P. A. Sci., Sławkowska 17, 31-016 Kraków]: Hypothesis on taxonomical status of Eptesicus sodalis and Myotis nathalinae. Bat Res. News, 24: 8.

LANGENFELD M. [Inst. Appl. Zool., Agric. Acad., Mickiewicza 24-28, 30-059 Kraków]: Obraz histologiczny zmienionych komórek nerwowych w zwojach pnia współczulnego nutrii (Myocastor coypus Mol.) - Histological picture of changing nerve cells in the ganglia of the sympathetic trunk of healthy nature coypu specimens (Myocastor coypus Mol.). Pol. Archwm wet., 23, 1: 159-167 [In Polish with English and Russ. summ.].

LEWANDOWSKI M. [Dept. Anim. Physiol., Jagiell. Univ., Karasia 6, 30-060 Kraków]: Seasonal differences in circadian acetylcholinesterase activity in the brain stem reticular formation of the mouse. Folia biol. 31, 4: 375-379 [Polish and russ. summ.].

ŁAKOMY M., see SZTEYN S. et al.

ŁAWRYNOWICZ Z., see ROMANIUK K. et al.

MAKOWIECKA M. (1), see WEGGRZYN M. \& MAKOWIECKA M.

MAKOWIECKA M. (2), see WĘGRZYN M. et al.

MĘCZYNSKI S. (1) [Inst. Biol., Dept. Comp. Anat. \& Anthropol. M. Curie-Sklodowska Univ., Akademicka 19, 20-033 Lublin]: Sezonowe zmiany morfologiczno-histologiczne narządów rozrodezych susła perelkowanego (Citellus suslicus Güldenstaedt, 1770). Część I. Narządy rozrodcze samców - Seasonal morphological-histological changes in the reproductive organs of souslik (Citellus suslicus Güldenstaedt, 1770). Part I. Male reproductive organs. Annls Univ. M. Curie-Skłodowska, C, 37 (1982), 1: 1-23 [In Polish with English and Russ. summ.].

MĘCZYŃSKI S. (2): Sezonowe zmiany morfologiczno-histologiczne narządów rozrodczych susła perełkowanego (Citellus suslicus Güldenstaedt, 1770). Część II. Na- 
rządy rozrodcze samic - Seasonal morphological-histological changes in the reproductive organs of souslik (Citellus suslicus Güldenstaedt, 1770). Part II. Female reproductive organs. Annls Univ. M. Curie-Skłodowska, C, 37 (1982), 2: 25-40 [In Polish with English and Russ. summ.].

NITECKA L., HASSLER R., BIAEOWAS J. \& WAGNER A. [Dept. Norm. Anat., Med. Acad., Dębinki 1, 80-211 Gdańsk]: The different types of synapses in the thalamic nucleus ventralis anterior (VA) of Saimiri sciureus and their degeneration after pallidum coagulation. J. Hirnforsch., 24, 2: 149-164.

ROMANIUK K., BUGAJAK P. \& ŁAWRYNOWICZ Z. [Fac. Vet. Sci., Agric., \& Techn. Acad., 17-957 Olsztyn-Kortowol: Inwazje pasożytów wewnętrznych u konika polskiego żyjącego na wolności i w chowie zamkniętym - Endoparasites infections in the Polish horse breed under free forest and stall breeding systems. Wiad. parazyt., 29, 3: 325-333 [In Polish with English summ.].

ROSKOSZ T., see.WEGRZYN M. et al.

ROSKOSZ T. \& KOBRYŃCZUK F. [Inst. Anim. Physiol., Warsaw Agric. Univ. - SGGW AR, Nowoursynowska 166, 02-766 Warszawa]: Determining the cranial cavity of the European bison, Bison bonasus (L., 1758) on the basis of chosen linear parameters of the cranium. Ann. Warsaw Agricult. Univ. - SGGW AR, Med. Vet., 11: 3-7 [Polish summ.].

SERWATKA S., see WĘGRZYN M. \& SERWATKA S.

SIKORA S.: Występowanie wydry $w$ Polsce - [Occurrence of the otter in Poland]. Łowiec pol., 12(1650): 12-13 [In Polish].

STRZAŁKA B. \& FLIEGER S. [Inst. Anim. Anat., Agric. Acad., Akademicka 12, 20-934 Lublin]: Ośrodki nerwowe ruchowe nerwu twarzowego (Nervus facialis) $\mathrm{u}$ wielbłada (Camelus dromedarius L.) - Motor nervous centres of the facial nerve (Nervus facialis) in the camel (Camelus dromedarius L.). Pol. Archwm vet. 23, 4: 145-154 [In Polish with English and Russ. summ.].

SZTEYN S., ŁAKOMY M., WYRZYKOWSKI Z. \& ZAMOJSKA D. [Dept. Zool.. Teacher Train. Coll., Żolnierska 14, 10-561 Olsztyn]: Nerwy cholinergiczne w układzie podwieszającym jajnik $u$ świni - Cholinergic nerves in the suspensatory system of the ovary in the pig. Pol. Archwm wet., 23, 4: 137-143 [In Polish with English and Russ. summ.].

TOMEK A., see KAEWA S. \& TOMEK A.

WALKOWA W., ADAMCZYK K. \& CHEEKOWSKA K. [Inst. Ecol, P. A. Sci., Dziekanów Leśny, 05-150 Łomianki]: Numbers and structure of rodent communities in the forest environment of Silesia. Pol. ecol. Stud., 8, 3-4 (1982): $305-330$ [Polish summ.].

WEGGRZYN M. \& MAKOWIECKA M. [Inst. Anim. Physiol., Warsaw Agric. Univ., Nowoursynowska 166, 02-766 Warszawa]: Thyroid arteries of the European bison, Bison bonasus (L., 1758). Ann. Warsaw Agricult. Univ. - SGGW AR, Med. vet., 11: 17-22 [Polish summ.].

WEGRZYN M., ROSKOSZ T. \& MAKOWIECKA M.: Brain arteries of the European bison, Bison bonasus (L., 1758). Ann. Warsaw Agricult. Univ. - SGGW AR, Med. vet., 11: 9-16 [Polish summ.].

WEGRZYN M. \& SERWATKA S.: The celiac artery and its ramifications in the European bison, Bison bonasus (L., 1758). Ann. Warsaw Agricult. Univ. - SGGW AR, Med. vet., 11: $23-30$ [Polish summ.].

WYRZYKOWSKI Z., see SZTEYN S. et al.

LAMOJSKA D., see SZTEYN S. et al.

ZUROWSKI W. [Inst. Gen. \& Anim. Breed., P. A. Sci., Res. St. Popielno, 12-222 Wejsuny]: Reconstitution de la population de castors Européens (Castor fiber L.) en Pologne. Carnets Zool., 43, 4: 59-62. 


\section{TITLES OF PAPERS PUBLISHED IN 1984}

ADAMCZEWSKA-ANDRZEJEWSKA K. A., see NABAGEO L. et al.

AMERSKI L., see DUDZIAK M. et al.

BARTECKI R., SE JACZEWSKI Z. \& BARTECKI R.

BIAEOWĄS J., HASSLER $\bar{R}$. \& WAGNER A. [Dept. Norm. Anat., Med. Acad., Dębinki 1, 80-211 Gdańsk]: Types of synapses and degeneration in the thalamic nucleus ventralis oralis posterior after cerebellar lesions in the squirrel monkey. J. Hirnforsch., 25, 4: 417-437.

BOBEK B. [Dept. Anim. Ecol., Jagiell. Univ., Karasia 6, 30-060 Kraków]: Management of a roe deer population in a deciduous forest in Southern Poland. Acta Zool. Fennica, 172: 241-242.

BOBEK B., see KRZYWIN̂SKI A. \& BOBEK B.

BORATYÑSKI Z. (1), see FLIEGER S. et al. (1)

BORATYNNSKI Z. (2), see FLIEGER et al. (2)

BORATYŃSKI Z. (3), see JASTRZĘBSKI M. et al.

BORATYŃSKI Z. (4), see SEAWOMIRSKI J. et al.

BORATYNSSKI Z. (5), see STRZAŁKA B. et al.

BORATYNSKI Z. (6), see WELENTO J. et al.

BORATYNSKI Z., FLIEGER S., JASTRZĘBSKI M. \& STRZAŁKA B. [Inst. Anim. Anat., Agric. Acad., Akademicka 12, 20-934 Lublin]: Budowa i topografia ośrodków nerwu podjęzykowego (nervus hypoglossus) w rdzeniu przedłużonym u łosia (Alces alces L.) - The structure and topography of the hypoglossal nerve centres (nervus hypoglossus) in medulla oblongata in the moose (Alces alces L.). Annls Univ. M. Curie-Skłodowska, DD, 35/36 (1980/81), 2: 7-19 [In Polish with English and Russ. summ.].

BORATYNTSKI Z., JASTRZEBSSKI M. \& FLIEGER S.: Ośrodki nerwu podjęzykowego (nervus hypoglossus) w rdzeniu przedłużonym u bizona (Bison bison L.) The centres of the hypoglossal nerve (nervus hypoglossus) in medulla oblongata of the Bison (Bison bison L.). Pol. Archwm wet., 24, 1: 139-146 [In Polish with English and Russ. summ.].

BOROWIECKI B., see SAMOL S. \& BOROWIECKI B.

BRUDNICKI R. (1), see JABEONSKI R. \& BRUDNICKI R.

BRUDNICKI R. (2), see WILAND C. \& BRUDNICKI R.

BRUSKI A., see JEZIERSKI W. \& BRUSKI A.

BUJALSKA G. \& MIESZKOWSKA D. [Inst. Ecol., P. A. Sci., Dziekanów Leśny, 05-092 Eomianki]: Distribution of individuals and captures in an island population of the bank vole. Acta theriol., 29, 11: 147-158 [Polish summ.].

CHWEDENCZUK K. \& LEHMAN-KRYSZAK M. [Zool. Garden, Ratuszowa 1/3, 03-461 Warszawa]: Sen foki szarej, Halichoerus grypus (Fab.) w warszawskim Ogrodzie Zoologicznym - The sleep of grey seal, Halichoerus grypus (Fab.) in Warsaw Zoo. Prz. zool., 28, 4: 535-540 [In Polish with English summ.].

CYBULSKI W., see WISLINNSKI M. et al.

CZARNOMSKA A., SITARZ M. \& ZBOROWSKA E. [Inst. Oncology, Wawelska 15, 00-973 Warszawa]: Kontrola genetyczna myszy laboratoryjnych. II. Analiza wybranych markerów morfologicznych i immunologicznych u myszy z 23 szczepów wsobnych - Genetic quality control of inbred mouse strains. II. Determination of some morphological and immunological markers in 23 inbred strains of mice. Zwierzęta Lab., 20 (1983), 1-2: 55-65 [In Polish with English summ.].

DANIEOS J. (1) [Clinic Gynaecol.-Obstetr., Med. Acad., Staszica 16, 20-081 Lublin]: Porównawcze badania aktywności niespecyficznej esterazy w korze nadner- 
czy szczurów młodych i starych - Comparative investigation of non-specific esterase activity in the adrenal cortex of young and old rats. Annls Univ. M. Curie-Skłodowska, D, 37 (1982), 12: 91-95 [In Polish with English and Russ. summ.].

DANIŁOS J. (2): Zawartość cholesterolu w korze nadnerczy szczurów (samic) młodych i starych - The content of cholesterol in the adrenal cortex of young and old rats (females). Annls Univ. M. Curie-Skłodowska, D, 37 (1982), 15. 109-114 [In Polish with English and Russ. summ.].

DANIŁOS J. (3: Zawartość fosfatazy zasadowej w korze nadnerczy szczurów (samic) młodych i starych - Contents of basic phosphatase in the adrenal cortex of young and old rats (females). Annls Univ. M. Curie-Skłodowska, D, 37 (1982), 13: 97-101 [In Polish with English and Russ. summ.].

DANIEOS J. (4): Zawartość kwasu askorbinowego w korze nadnerczy szczurów (samic) młodych i starych - The content of ascorbic acid in the adrenal cortex of young and old rats (females). Annls Univ. M. Curie-Skłodowska, D, 37 (1982), 14: 103-107 [In Polish with English and Russ. summ.].

DASHZEVEG D. \& KIELAN-JAWOROWSKA Z.: The lower jaw of an aegialodontid mammal from the Early Cretaceous of Mongolia. Zool. J. Linn. Soc. Lond., 82: 217-227.

DOBROWOLSKA A. \& GROMADZKA-OSTROWSKA J. [Dept. Anim. Physiol., Warsaw Univ., Żwirki i Wigury 93, 02-089 Warszawa]: Age and androgen-related changes in morphological parameters, haematological indices and serum protein fraction in common vole (Microtus arvalis Pall.) growing in different photoperiods. Comp. Biochem. Physiol. A, 79, 2: 241-249.

DUDZIAK M., SZOSTAKIEWICZ-SAWICKA H. \& AMERSKI L. [Dept. Norm. Anat., Med. Acad., Debinki 6, 80-211 Gdańsk]: Septomarginal trebecula in the right cardic ventricle of some carnivores. Folia morph., 43, 3: 271-275 [Polish summ.]. DYDYK L. [Medical Res. Centre, P. A. Sci., Dworkowa 3, 00-784 Warszawa]: Ultrastruktura nadnercza u krolika - Ultrastructure of the adrenals in the rabbit. Zwierzęta Lab., 20 (1983), 1-2: 13-18 [In Polish with English summ.].

DYRCZOWA A. [Dept. Comp. Anat., Wrocław Univ., Sienkiewicza 21, 50-335 Wrocław]: The male reproductive tracts in four species of geomyoid rodents with respect of their systematic position (Geomyoidea, Rodentia). Zool. Pol., 29 (1982), 3-4: 201-208 [Polish summ.].

DZIECIOEOWSKI R. M. [Dept. Soil, Crop Sci. Forest., Fac. Agric., Rivers State Univ. Sci. Technol., Port Harcourt, PMB 5080, Nigeria]: Forestry versus big game. Acta Zool. Fennica, 172: 157-158.

EUSTACHIEWICZ R. (1), see FLIEGER S. et al.

EUSTACHIEWICZ R. (2), see WELENTO J. et al.

FEDYK S., GËBCZYŃSKA Z., PUCEK M., RACZYNNSKI J. \& SIKORSKI M. D. [Mammals Res. Inst., P. A. Sci., 17-230 Białowieża]: Winter penetration by mammals of different habitats in the Biebrza valley. Acta theriol., 29, 27: 317-336 [Polish summ.].

FEDYK S., see WOJCIK A. M. \& FEDYK S.

FLIEGER S. (1), see BORATYŃSKI Z. et al.

FLIEGER S. (2), see BORATYŃSKI Z. et al.

FLIEGER S. (3), see JASTRZĘBSKI M. et al.

FLIEGER S. (4), see JASTRZĘBSKI M. et al.

FLIEGER S. (5), see SEAWOMIRSKI J. et al.

FLIEGER S. (6), see STRZAEKA B. et al.

FLIFGER S. (7), see WELENTO J. et al.

FLIEGER S., BORATYNSSKI Z., WELENTO J., EUSTACHIEWICZ R., SZALAK M., KRZYZANOWSKI .T. \& SEAWOMIRSKI .I. [Inst. Anim. Anat., Agric. Acad,, 
Akademicka 12, 20-934 Lublin]: Eksperymentalne badania nad lokalizacją ośrodków nerwowych jajnika i jajowodu u krowy - Experimental studies on localization of the nervous centres of ovary and oviduct in the cow. Pol. Archwm wet., 24, 2: $261-273$ [In Polish with English and Russ. summ.].

FLIEGER S., SEAWOMIRSKI J., BORATYŃSKI Z. \& JASTRZĘBSKI M.: Nucleus motorius lateralis w odcinku lędźwiowo-krzyżowym rdzenia kręgowego u konia - Nucleus motorius lateralis in the lumbar-sacral segment of the spinal cord in the horse. Pol. Archwm wet., 24, 1: 125-131 [In Polish with English and Russ. summ.].

FLIEGER S., STRZAEKA B. \& JASTRZĘBSKI M.: Ośrodki nerwów czaszkowych: okoruchowego (III), bloczkowego (IV) i odwodzącego (VI) u wielbłąda (Camelus dromedarius L.) - Centres of cranial nerves: oculomotor (III), trochlear (IV) and abducens (VI) in the camel (Camelus dromedarius L.). Pol. Archwm wet., 24, 2: 253-260 [In Polish with English and Russ. summ.].

GEBLER E., see JEZIERSKI T. \& GEBLER E.

GĘBCZYŃSKA Z. \& RACZYŃSKI .J. [Mammals Res. Inst., P. A. Sci., 17-230 Białowieża]: Habitat preferences and population structure of moose in the Biebrza river valley. Acta Zool. Fennica, 172: 93-94.

GĘBCZYŃSKA Z., see GĘBCZYŃSKI M. \& GĘBCZYŃSKA Z.

GĘBCZYN̂SKA Z., see FEDYK S. et al.

GĘBCZYŃSKI M. \& GĘBCZYŃSKA Z. [Mammals Res. Inst., P. A. Sci., 17-230 Białowieża]: The energy cost of nesting growth in the European pine vole. Acta theriol., 29, 18: 231-241 [Polish summ.].

GIENC J. \& KUDER T. [Lab. Anat., Pedagogic. Coll. Rewolucji Październikowej 33, 25-518 Kielce]: Cytoarchitectonics of the trigeminal ganglion of the guinea pig. Zool. Pol., 29 (1982), 3-4: 209-217 [Polish and Russ. summ.].

GLIWICZ J. (1) [Dept. Wildl. Manage., Warsaw Agric. Univ., Rakowiecka 26/30, 02-528 Warszawa]: Competition among forest rodents: Effects of Apodemus flavicollis and Clethrionomys glareolus on A. agrarius. Acta Zool. Fennica, 172: $57-60$.

GLIWICZ J. (2): Rodents on islands: living in a crowd. Acta Zool. Fennica, 172: 95-98.

GRODZIŃSKI W. \& WEINER J. [Dept. Anim. Ecol., Jagiell. Univ., Karasia 6, 30-060 Kraków]: Energetics of small and large mammals. Acta Zool. Fennica, 172: $7-10$.

- GRODZIŃSKI W., WEINER J. \& MAYCOCK P. F. (Eds) [Dept. Anim. Ecol., Jagiell. Univ., Karasia 6, 30-060 Kraków]: Forest ecosystems in industrial regions. Ecol. studies 49, Springer Verl., Berlin, 277 pp.

GROMADZKA J., see SYSA P. S. et al.

GROMADZKA-OSTROWSKA J. (1), see DOBROWOLSKA A. \& GROMADZKA-OSTROWSKA J.

GROMADZKA-OSTROWSKA J. (2), see JAKUBOW K. et al.

GROMADZKA-OSTROWSKA J. (3), see JAKUBOW K. et al.

GROMADZKA-OSTROWSKA J. \& SZYLARSKA-GOŹDŹ E. [Physiol, Lab., Warsaw Zool. Garden, Ratuszowa 1/3, 03-461 Warszawa]: Progesterone concentration and their seasonal changes during the estrus cycle of chinchilla. Acta theriol., 29, 20: 251-258 [Polish summ.].

GROMADZKA-OSTROWSKA J. \& ZALEWSKA B.: Changes in protein fractions in blood plasma of female chinchillas during pregnancy and lactation. Acta theriol., 29, 19: $243-250$ [Polish summ.].

HAITLINGER R. (1) [Inst. Biol. Fund. Anim. Prod., Agric. Acad., Cybulskiego $20,50-205$ Wrocław]: Stawonogi występujące na Crocidura suaveolens (Pall.), (Mammalia, Insectivora) w Polsce ze szczególnym uwzględnieniem aglomeracji miejskiej - Arthropods of Crocidura suaveolens (Pall.), (Mammalia, Insectivora) in Poland mainly in urban agglomeration. Wiad. parazyt., 30, 4: 521-529 [In Polish with English summ.]. 
HAITLINGER R. (2): Stawonogi występujące w Polsce na Neomys fodiens (Penn.) i Neomys anomalus Cabr. (Mammalia, Insectivora) - Arthropods occuring on Neomys fodiens (Penn.) and Neomys anomalus Cabr. (Mammalia, Insectivora) in Poland. Wiad. parazyt., 30, 5-6: 603-616 [In Polish with English summ.].

HAITLINGER R. (3): Zgrupowania stawonogów występujących na Sorex araneus L. i Sorex minutus L. w środowisku leśnym i bezleśnym Wzgórz Niemczańskich - Arthropods groups of Sorex araneus L. and Sorex minutus L. from forest and forestless environment of Niemczańskie Hills. Wiad. parazyt., 30, 3: 345-367 [In Polish with English summ.].

HEREC S., MILART Z. \& SZALAK M. [Inst. Anim. Anat., Agric. Acad., Akademicka 12, 20-934 Lublin]: Włókna wstẹpujące i zstępujące korzeni dogrzbietowych nerwów piersiowych I-VI u owcy - Ascending and descending fibres of the dorsal roots of the thoracal nerves I-IV in sheep. Annls Univ. M. Curie-Skłodowska, DD, 37 (1982), 1: 1-10 [In Polish with English and Russ. summ.].

HEREC S., see MILART Z. et al.

JABEONSKI R. \& BRUDNICKI R. [Dept. Anim. Physiol. \& Anat., Inst. Zootechn. Technic.-Agric. Acad., Bernardyńska 6, 85-029 Bydgoszcz]: The effect of blood distribution to the brain on the structure and variability of the cerebral arterial circle in musk-rat and in chinchilla. Folia morph., 43, 2: 109-114 [Polish summ.]. JACZEWSKI Z. (1) [Inst. Gen. \& Anim. Breed., P. A. Sci., Res. St. Popielno, 12-222 Wejsumy]: Observations on the aggressive and sexual behaviour of red deer (Cervus elaphus L.). Deer, 6, 3: 85-87.

JACZEWSKI Z. (2): O wielkości łosi europejskich - [Body size of the European moose]. Łowiec pol. 6: 18 [In Polish].

JACZEWSKI Z. \& BARTECKI R.: Effects of oestradiol and dihydrotestosterone on the behaviour and antler cycle of castrated red deer males. Acta Zool. Fennica, 171: 209-211.

JAKUBOW K., GROMADZKA-OSTROWSKA J. \& ZALEWSKA B. [Physiol. Lab., Warsaw Zool. Garden, Ratuszowa 1/3, 03-461 Warszawa]: Seasonal changes in the haematological indices in peripheral blood of chinchilla (Chinchilla laniger L.). Comp. Biochem. Physiol. A, 78, 4: 845-853.

JAKUBOW K., GROMADZKA-OSTROWSKA J., ZALEWSKA B. \& SZYLARSKA-GOŹDŹ E.: Zmiany w morfologicznym obrazie krwi podczas cyklu estralnego prymitywnych przedstawicieli rodzaju Sus - Haematological changes during oestrus cycle of primitive exponent of Sus genus. Med. wet., 40, 6: $351-356$ [In Polish with English and Russ. summ.].

JANION S. M. \& MALINOWSKI W. [Inst. Ecol., P. A. Sci., Dziekanów Leśny, 05-150 Łomianki]: Alternations of group size in populations of white mice (Mus musculus L.) caused by ultrasounds. Bull. Pol. Acad. Sci., Biol., Sci., 37, 7-8: 251-255 [Russ. summ.].

JASTRZĘBSKI M. (1), see BORATYNSKI Z. et al.

JASTRZĘBSKI M. (2), see BORATYŃNKI Z. et al.

JASTRZĘBSKI M. (3), see FLIEGER S. et al.

JASTRZEBBSKI M. (4), see FLIEGER S. et al.

JASTRZĘBSKI M. (5), see SEAWOMIRSKI J. et al.

JASTRZĘBSKI M. (6), see STRZAEKA B. et al.

JASTRZEBSKI M., BORATYŃSKI Z. \& FLIEGER S. [Inst. Anim. Anat., Agric. Acad., Akademicka 12, 20-934 Lublin]: Budowa i topografia oliwki (nucleus olivaris) losia (Alces alces L.) - The structure and topography of nucleus olivaris of the moose (Alces alces L.). Annls Univ. M. Curie-Skłodowska, DD, 37 (1982), 2: $21-29$ [In Polish with English and Russ, summ.].

JASTRZĘBSKI M., FLIEGER S., WELENTO J. \& EAKOMY M.: Ośrodki nerwu podjęzykowego (nervus hypoglossus) wielbłąda (Camelus dromedarius L.) - The centres of the hypoglossal nerve (nervus hypoglossus) of the camel (Camelus dro- 
medarius L.). Pol. Archwm wet., 24, 1: 117-124 [In Polish with English and Russ. summ.].

JEZIERSKI W. \& BRUSKI A. [Dept. Ecol., Teacher Train. Coll., Zołnierska 14 10-561 Olsztyn]: Damage cause in tree stands by small populations of moose. Acta Zool. Fennica, 172: 193-194.

JEZIERSKI T. \& GEBLER E. [Inst. Gen. \& Anim. Breed., P. A. Sci., Jastrzebiec, 05-551 Mroków]: Observations on behaviour of Polish feral horses. Z. Tierzüchtg. Züchtgsbiol., 101, 2: 143-152 [In German with English, French and Spanish summ.]. JOZEFCZAK E., see WOEK E. \& JOZEFCZAK E.

KAEUZIŃSKI J., see SYSA P. S. \& KAEUZIŃSKI J.

KASZUBA S., see ROMANOWSKI J. et al.

KIELAN-JAWOROWSKA Z. (1) [Palaeobiol. Inst., P. A. Sci., Żwirki i Wigury 93, 02-089 Warszawa]: Evolution of the therian mammals in the Late Cretaceous of Asia. Part V. Skull structure in Zalambdalestidae. Palaeont. Pol., 46: 107-117 [Polish summ.].

KIELAN-JAWOROWSKA Z. (2): Evolution of the therian mammals in the Late Cretaceous of Asia. Part VI. Endocranial casts of eutherian mammals. Palaeont Pol., 46: 157--171 [Polish summ.].

KIELAN-JAWOROWSKA Z. (3): Evolution of the therian mammals in the Late Cretaceous of Asia. Part VII. Synopsis. Palaeont. Pol., 46: 173-183 [Polish summ.]. KIELAN-JAWOROWSKA Z. (4), see DASHZEVEG D. \& KIELAN-JAWOROWSKA Z. KIELAN-JAWOROWSKA Z., POPLIN C., PRESLEY R. \& RICQLES A.: Preliminary note on multituberculate cranial anatomy studied by serial sections. In "Short papers, Third Symp. Mesozoic Terrestrial Ecosyt.", Eds W. E. Reif \& F. Westphal. Atempto, Tübingen: $123-128$.

KLEVEZAL G. A., PUCEK M. \& MALAFEEVA E. P.: Body and skeleton growth in laboratory field voles of different seasonal generations. Acta theriol., 29, 1: 3-16 [Polish summ.].

KNASIECKA V. [Dept. Anim. Anat., Agric. Acad., Wojska Polskiego 71c, 60-625 Poznań]: Główne tetnice łuku aorty i sposób odejścia ich gałezi u nutrii Myocastor coypus (Molina, 1782) - The main arteries of aortic arch and the way of their branching in nutria Myocastor coypus (Molina, 1782). Roczn. Acad. roln. Poznań, 148, Zootechn. 31: 81-95 [In Polish with English and Russ. summ.].

KORWIN-KOSSAKOWSKI J. \& SUMIN̂SKI E. [Mickiewicza 33 D/7, 01-625 Warszawa]: Development of gonads and spermatogenesis in hybrids of European bison and domestic cattle. Acta theriol., 29, 34: 413-424 [Polish summ.].

- KOWNACKI M. [Inst. Breed. \& Techn. Anim. Prod., Agric. Teacher's Train. Coll., B. Prusa 12, 08-110 Siedlce]: Koniki polskie - Polish primitive horses. PWN, Warszawa, $78 \mathrm{pp}$. [In Polish with English and Russ. summ.].

KOZAKIEWICZ B. \& MASZEWSKA I. [Dept. Vet. Hyg., Grunwaldzka 250, 60-166 Poznańl: Wystepowanie i leczenie parazytoz muflonów (Ovis musimon L.) w warunkach hodowli w ośrodku łowieckim w Wielkopolsce - The occurrence and treatment of parasites in mouflons in the hunting center in the Wielkopolska district. Med. wet., 40, 9: 536-538 [In Polish with English and Russ. summ.]. KOŹNIEWSKI P., see ROMANOWSKI J. et al.

KRUMINIS-ŁOZOWSKA W., see WEGNER Z. \& KRUMINIS-ŁOZOWSKA W.

KRZANOWSKI A. (1) [Dept. Syst. \& Exp. Zool., P. A. Sci., Sławkowska 17, 31-016 Kraków]: Causes of depauperation of the molossid fauna in the Indo-Australian region. Bat Res. News, 25: 5-6.

KRZANOWSKI A. (2): Etologiczna koewolucja żab i nietoperzy - [Ethological coevolution of the frogs and bats]. Wszechświat, 85: 4-6 [In Polish].

KRZYWINSKI A. \& BOBEK B. [Inst. Gen. \& Anim. Breed., P. A. Sci., Res. St. 
Popielno, 12-222 Wejsuny]: Semen collection from red deer males with a dummy. Acta Zool. Fennica, 172: 175-178.

KRZYWINSSKI A., NIEDBALSKA A. \& TWARDOWSKI L.: Growth and development of hand reared fallow deer fawns. Acta theriol., 29, 29: 349-356 [Polish summ.].

KRZYWINSSKI A., WIERZCHOS E. \& SMORĄG Z.: Observations on recovering and freezing red deer embryo. Acta theriol., 29, 24: 291-295 [Polish summ.].

KRZYZANOWSKI J. (1), see FLIEGER S. et al.

KRZYZANOWSKI J. (2), see WELENTO J. et al.

KUBIK J., LENIEC W. \& SITKOWSKI W. [Inst. Biol. Dept. Comp. Anat. \& Anthropol., M. Curie-Skłodowska Univ., Akademicka 12, 20-033 Lublin]: Analysis of the mammal fauna of the Lublin coal basin based on owl pellets. Acta theriol., 29, 13: 167-173 [Polish summ.].

KUDER T. (1) [Lab. Anat., Pedagogic. Coll., Rewolucji Październikowej 33, 25-518 Kielce]: Comparative morphology and topography of cranial parasympathetic ganglia connected with the trigeminal nerve in mouse, rat and hamster (Mus musculus L., 1759, Rattus norvegicus B., 1769, Mesocricetus auratus W., 1839). Part III. Mandibular and sublingual ganglia. Folia morph., 43, 1: 19-34 [Polish summ.].

KUDER T. (2), see GIENC J. \& KUDER T.

LAMPRECHT J., see ROWIŃSKI J. et al.

LASOTA-MOSKALEWSKA A. [Ateliers for Conservation of Cultural Properties, Senatorska 14, 00-950 Warszawa]: The skeleton of a prehistoric cow with characteristics of both primigenious and brachycerous cattle. Ossa, 9-11: 53-72.

LEHMAN-KRYSZAK M., see CHWEDEÑCZUK K. \& LEHMAN-KRYSZAK M. LENIEC W., see KUBIK J. et al.

LESINSKI G. [Inst. Ecol., P. A. Sci., Dziekanów Leśny, 05-150 Łomianki]: W sprawie ochrony zimowiska nietoperzy w jaskini Szachownica na Wyżynie Wieluńskiej - An appeal for the protection of the winter quarters of bats in the Szachownica Cave on the Wiluń Upland. Chrońmy Przyr. ojcz., 40, 2: 52-55 [In Polish].

LESNICZAK A. B.: Wydra Lutra lutra na Opolszczyźnie - The otter, Lutra lutra in the region of Opole. Chrońmy Przyr. ojcz., 40, 5-6: 84-85 [In Polish].

ŁAKOMY M. (1), see JASTRZĘBSKI M. et al.

モAKOMY M. (2), see SZTEYN S. \& ŁAKOMY M.

モAZUGA--ADAMCZYK A., see WISLIŃSKI M. et al.

MACKIN-ROGALSKA R., see NABAGEO L. et al.

MAJEWSKA-MICHALSKA E. [Dept. Neuroanat., Inst. Zool., Jagiell. Univ., Karasia 6, 30-060 Kraków]: Blood supply of the tegmentum mesencephali in dog. Folia morph., 43, 1: 35-41 [Polish summ.].

MALINOWSKI W., see JANION S. M. \& MALINOWSKI W.

MAMOS L. [Dept. Norm. Anat., Med. Acad., Dębinki 1, 80-211 Gdańsk]: Morphology of claustral neurons in the rat. Folia morph., 43, 2: 73-78 [Polish summ.].

MASZEWSKA I., see KOZAKIEWICZ B. \& MASZEWSKA I.

MATUSZEWSKI G. \& SUMINSKI P. [Forestry Res. Inst., Wery Kostrzewy 3, 02-362 Warszawa]: Sika deer in Poland. Deer, 6, 3: 74-75.

MAZURKIEWICZ M. [Inst. Ecol., P. A. Sci., Dziekanów Leśny, 05-150 Łomianki]: Population density of small rodents as affected by chosen elements of tree stand structure. Bull. Pol. Acad. Sci., Biol. Sci., 32, 5-6: 209-217 [Russ. summ.].

MIESZKOWSKA D., see BUJALSKA G. \& MIESZKOWSKA D. 
MILART Z., HEREC S. \& SZALAK M. [Inst. Anim. Anat., Agric. Acad., Akademicka 12, 20-934 Lublin]: Topografia neuronów ruchowych nerwu pośrodkowego w rdzeniu kregowym owcy - Topography of the motoneurons of median nerve in the spinal cord of sheep. Annls Univ. M. Curie-Skłodowska, DD, 35/36 (1980/1981), 1: $1-5$ [In Polish with English and Russ. summ.].

MILART Z., see HEREC S. et al.

MIŁKOWSKI L. \& WOJCIK J. M. [Krzyże 15, 17-230 Białowieża]: Structure of wild boar harvest in the Białowieża Primeval Forest. Acta theriol., 29, 28: 337-347 [Polish summ.].

NABAGEO L., ADAMCZEWSKA-ANDRZEJEWSKA K. A. \& MACKIN-ROGALSKA R. [Inst. Ecol., P. A. Sci., Dziekanów Leśny, 05-092 Łomianki]: Trappability and distribution of individual captures in a common vole population. Acta theriol., 29, 12: 159-166 [Polish summ.].

NADACHOWSKI A. (1) [Inst. Syst. \& Exp. Zool., P. A. Sci., Sławkowska 17, 31-016 Kraków]: Morphometric variability of dentition of the Late Pleistocene voles (Arvicolidae, Rodentia) from Bacho Kiro Cave (Bulgaria). Acta zool. cracov., 27, 9: 149-176 [Polish summ.].

NADACHOWSKI A. (2): On a collection of small mammals from the Peoples Democratic Republic of Korea. Acta zool. cracov., 27, 3: 47-60 [Polish summ.].

NADACHOWSKI A. (3): Taxonomic value of anteroconid measurements of $\mathrm{M}_{1}$ in common and field voles. Acta theriol.. 29, 10: 123-127.

NAGORNA-STASIAK B., see WISLIN̂SKI M. et al.

NIEDBALSKA A., see KRZYWIŃSKI A. et al.

OKARMA H. [Dept. Anim. Ecol., Jagiell. Univ., Karasia 6, 30-060 Kraków]: The physical condition of red deer falling a prey to the wolf and lynx and harvested in the Carpathian Mountains. Acta theriol., 29, 23: 283-290 [Polish summ.].

OŻDŻEŃSKI W. \& PRESZ M. [Dept. Embryol., Inst. Zool., Warsaw Univ., Krakowskie Przedmieście 26/28, 00-927 Warszawa]: Precocious initiation of meiosis by male germ cells of the mouse. Archs Anat. microsc. Morph. exp., 73, 1: 1-7.

PARUSEL J. B. (1) [Babia Góra Nat. Park, 34-223 Zawoja]: Ochrona i hodovila żubrów w Pszczynie w latach 1979-1981 - Protection and breeding of European bisons in Pszczyna in 1979-1981. Parki nar. Rez. Przyr., 5, 2: 39-44 [In Polsh with English summ.].

PARUSEL J. B. (2): Tropienie niedźwiedzia Ursus arctos w Babiogórskim Parku Narodowym - Tracking a brown bear, Ursus arctos, in the Babia Góra National Park. Chrońmy Przyr. ojcz., 40, 5-6: 50-56 [In Polish].

- PIELOWSKI Z. (1) [Polish Hunting Assoc., Res. St., 64-020 Czempiń]: Sama - [Roe deer.] II ed. PWRiL, Warszawa, 287 pp. [In Polish].

PIELOWSKI Z. (2): Some aspects of population structure and longevity of field roe deer. Acta theriol., 29, 2: 17-33 [Polish summ.].

PRESZ M., see OŻDŻEŃNKI W. \& PRESZ M.

PUCEK M. (1), see FEDYK S. et al.

PUCEK M. (2), see KLEVEZAL G. A. et al.

- PUCEK Z. (Ed.) (1) [Mammals Res. Inst., P. A. Sci., 17-230 Białowieża]: Klucz do oznaczania ssaków Polski - [Keys to Polish mammals]. II ed. PWN, Warszawa, $384 \mathrm{pp}$. [In Polish].

PUCEK Z. (2): What to do with the European bison, now saved from extinction? Acta Zool. Fennica, 172: 187-190.

RACHOWIAK P. [Dept. Syst. Zool., A. Mickiewicz Univ., Fredry 10, 61-701 Poznań]: Przypadek anomalii barwnej u ryjówkowatych (Soricidae) - częściowy al- 
binizm u ryjówki aksamitnej, Sorex araneus Linnaeus, 1758 - The case of colour anomaly in shrews - white spotted specimen of common shrew. Prz. zool., 28, 4: $549-551$ [In Polish with English summ.].

RACZYNSKI J. (1), see FEDYK S. et al.

RACZYŃSKI J. (2), see GĘBCZYŃSKA Z. \& RACZYŃSKI J.

REICHERT M., see WISLIŃSKI M. et al.

ROMAN G. [Dept. Biol., Warsaw Univ, Div., Sosnowa 64, 15-887 Bialystok]: The burrow construction strategy of foxes in the Białowieża Primeval Forest. Acta theriol. 29, 35: 425-430 [Polish summ.].

ROMANOWSKI J., KASZUBA S. \& KOŹNIEWSKI P. [Sardyńska 3/7, 02-761 Warszawa]: Nowe dane o występowaniu norek (Mammalia, Mustelidae) w Polsce - New data on the occurrence of minks (Mammalia, Mustelidae) in Poland. Prz. zool., 28, 2: 221-223 [In Polish with English summ.].

ROWINSKI J., LAMPRECHT J. \& SICIŃSKI P. [Dept. Hist. \& Embryol., Med. Acad., Chałubińskiego 5, 02-004 Warszawa]: Distribution of the lymphoid cells in the intestinal epithelium of mice a preliminary communication. Folia morph., 43, 2: 105-107 [Polish summ.].

RUPRECHT A. L. [Mammals Res. Inst., P. A. Sci., 17-230 Białowieża]: W sprawie polskich nazw zoologicznych dla krajowych nietoperzy - Remarks concerning vernacular names for Polish bats. Prz. zool., 28, 2: 215-220 [In Polish with English summ.].

SAMOL S. \& BOROWIECKI B. [Dept. Vet. Hyg., Lechnicka 21, 02-156 Warszawa]: Występowanie wścieklizny u jenotów (Nyctereutes procyonoides) na terenie Polski - Prevalence of rabies in raccon dogs (Nyctereutes procyonoides) in Poland. Med. wet., 40, 7: 407-409 [In Polish with English and Russ. summ.].

SERWATKA S., see WĘGRZYN M. \& SERWATKA S.

SICIŃSKI P., see ROWIŃSKI P. et al.

SIKORA S. [Dept. Appl. Zool., Agric. Acad., Al. Wojska Polskiego 71c, 60-625 Poznań]: Wydra Lutra lutra (L.) o czarnym zabarwieniu - An otter Lutra lutra (L.) of black coloration. Prz. zool., 28, 4: 553-554 [In Polish].

SIKORSKI M. D. \& BERHSHTEIN A. D. [Mammals Res. Inst., P. A. Sci., 17-230 Białowieża]: Geographical and intrapopulation divergence in Clethrionomys glareolus. Acta theriol., 29, 17: 219-230 [Polish summ.].

SIKORSKI M. D., see FEDYK S. et al.

SITARZ M., see CZARNOMSKA A. et al.

SITKOWSKI W., see KUBIK J. et al.

SEAWOMIRSKI J. (1), see FLIEGER S. et al.

SEAWOMIRSKI J. (2), see FLIEGER S. et al.

SŁAWOMIRSKI J. (3), see SYSA P. S. et al.

SŁAWOMIRSKI J. (4), see WELENTO J. et al.

SEAWOMIRSKI J., FLIEGER S., JASTRZEBSKI M. \& BORATYNSKI Z. [Inst. Anim. Anat., Agric. Acad., Akademicka 12, 20-934 Lublin]: Nucleus motorius medialis $\mathrm{w}$ odcinku lędźwiowo-krzyżowym rdzenia kręgowego u konia - Nucleus motorius medialis in the lumbar-sacral segment of the spinal cord in the horse. Pol. Archwm wet., 24, 1: 133-137 [In Polish with English and Russ. summ.].

SMORĄG Z., see KRZYWIŃSKI A. et al.

STRZAEKA B. (1), see BORATYŃSKI Z. et al.

STRZAEKA B. (2), see FLIEGER S. et al.

STRZAŁKA B. (3), see WELENTO J. et al.

STRZAEKA B., FLIEGER S., BORATYŃSKI Z. \& JASTRZEBSKI M. [Inst. Anim. Anat., Agric. Acad., Akademicka 12, 20-934 Lublin]: Budowa i topografia jądra: 
przywspółczulnego nerwów językowo-gardłowego i błędnego oraz jądra dwuznacznego w rdzeniu przedłużonym u losia (Alces alces L.) - The structure and topography of the parasympathetic nucleus of the glosso-pharyngeal and vagus nerves and of the ambiguus nucleus in medulla oblongata in the moose (Alces alces L.). Annls Univ. M. Curie-Skłodowska, DD, 37 (1982), 2: 11-20 [In Polish with English and Russ. summ.].

SUMINSSKI E., see KORWIN-KOSSAKOWSKI J. \& SUMIŃNKI E.

SUMINSKI P., see MATUSZEWSKI G. \& SUMIÑSKI P.

SYSA P. S. \& KAEUZIN̂SKI .J. [Fac. Vet. Med., Warsaw Agric., Univ., Nowoursynowska 166, 02-766 Warszawa]: Possibility of freemartinism in roe deer. Acta theriol., 29, 10: 133-137 [Polish summ.].

SYSA P. S., SEAWOMIRSKI J. \& GROMADZKA J.: Uwagi na temat badań cytogenetycznych nad krzyżówką dzika (Sus scrofa ferus) i świni domowej (Sus scrofa dom.) - Remarks on cytogenetic studies on crossing the wild boar (Sus scrofa ferus) and the domestic pig (Sus scrofa dom.). Pol. Archwm wet., 24, 1: 89-95 [In Polish with English and Russ. summ.].

SZALAK M. (1), see FLIEGER S. et al.

SZALAK M. (2), see HEREC S. et al.

SZALAK M. (3), see MILART Z. et al.

SZALAK M. (4), see WELENTO J. et al.

SZATKOWSKA C. [Inst. Fund. Vet, Sci., ART Olsztyn-Kortowo]: Budowa i topografia jąder móżdżku nornicy rudej (Clethrionomys glareolus) i myszy leśnej (Apodemus flavicollis) - Structure and topography of cerebellum nuclei in Clethrionomys glareolus and Apodemus flavicollis. Zesz. nauk. ART Olsztyn 247, Wet. 14: 11-23 [In Polish with English and Russ. summ.].

SZOSTAKIEWICZ-SAWICKA H., see DUDZIAK M. et al.

SZTEYN S. \& ŁAKOMY M. [Dept. Zool., Teacher Train. Coll., Zolnierska 14, 10-561 Olsztyn]: Nerwy adrenergiczne w aparacie podwieszającym jajnik u świni - Adrenergic nerves in the suspensory apparatus of ovarium in the pig. Pol. Archwm wet., 24, 2: 275-280 [In Polish with English and Russ. summ.].

SZUKIEL E. [Forestry Res. Inst., Wery Kostrzewy 3, 02-362 Warszawa]: Szkody łowieckie w polskich lasach - Game damage in Polish forests. Sylwan, 128, 3: 47-56 [In Polish with English and Russ. summ.].

SZYLARSKA-GOŹDŹ E., see JAKUBOW K. et al.

SZYLARSKA-GOŹDŹ E., see GROMADZKA-OSTROWSKA J. \& SZYLARSKA-GOŹDŹ E.

SMIEŁOWSKI J. [Inst. Appl. Zool., Agric., Acad., Al. Wojska Polskiego 71c, 60-625 Poznań]: Rozmnażanie i przeżywalność pumy Felis concolor Linnaeus, $1766 \mathrm{w}$ warunkach Zoo - Breeding and survival of puma, Felis concolor Linnaeus, 1766 in the Zoo environment. Roczn. Acad. roln. Poznań, 148, Zootechn. 31: 201-212 [In Polish with English and Russ. summ.].

TOMASZEWSKA-GUSZKIEWICZ K. \& ZURKOWSKI M. [Inst. Gen. \& Anim. Breed., P. A. Sci., Jastrzębiec, 05-551 Mroków]: Zastosowanie badań genetycznego polimorfizmu białek krwi koni w kontroli pochodzenia - Application of genetic polymorphism of blood proteins in horses for parentage control. Pr. mat. Zootechn., 31: 77-81 [In Polish].

TWARDOWSKI L., see KRZYWIN̂SKI A. et al.

WEGNER Z. \& KRUMINIS-EOZOWSKA W. [Inst. Martime \& Tropical Med. Starowiejska 50, 81-356 Gdynia]: Ectoparasites of rats collected in the Port and City of Gdańsk. Acta parasit. pol., 29, 15: 117-128 [Polish summ.].

WEINER J. (1), see GRODZIŃSKI W. \& WEINER J.

WEINER J. (2), see GRODZIN̂SKI W. et al.

WELENTO J. (1), see FLIEGER S. et al. 
WELENTO J. (2), see JASTRZĘBSKI M. et al.

WELENTO J., FLIEGER S., BORATYŃSKI Z., KRZYZANOWSKI J., STRZAEKA B., SEAWOMIRSKI J., SZALAK M. \& EUSTACHIEWICZ R. [Inst. Anim. Anat., Agric., Acad., Akademicka 12, 20-934 Lublin]: Experimental investigations on localization of the nerve centres concerned in the in- nervation of the ovary and the uterine tube in pig. Folia morph., 43, 2: 85-90 [Polish summ.].

WEGRZYN M. \& SERWATKA S. [Inst. Anim. Physiol., Warsaw Agric. Univ., Nowoursynowska 166, 02-766 Warszawa]: Teeth eruption in the European bison. Acta theriol., 29, 9: 111-121 [Polish summ.].

WIEKZCHOS E., see KRZYWIŃSKI A. et al.

WILAND C. \& BRUDNICKI R. [Dept. Anim. Physiol. \& Anat., Technic.-Agric. Acad., Bernardyńska 6, 85-029 Bydgoszcz]: Multiple middle cerebral arteries in various species of mammals. Folia morph., 43, 3: 265-270 [Polish summ.].

WISLINSKI M., NAGORNA-STASIAK B., EAZUGA-ADAMCZYK A., REICHERT M. \& CYBULSKI W. [Dept. Anim. Physiol., Vet. Fac., Agric. Acad., Akademicka 12, 20-033 Lublin]: Niektóre wskaźniki hematologiczne i zmiana Hb F przez $\mathrm{Hb} \mathrm{B}$ $\mathrm{u}$ jagniąt $\mathrm{w}$ pierwszych dwóch miesiącach życia - Some haematological indices and the change of $\mathrm{Hb} \mathrm{F}$ by $\mathrm{Hb} \mathrm{B}$ in young lambs in the first two months of their life. Med. wet., 40, 4: 242-245 [In Polish with English and Russ. summ.].

WOLSAN M. (1) [Inst. Syst. \& Exp. Zool., P. A. Sci., Sławkowska 17, 31-016 Kraków]: An incisor with double crown in a stoat (Mustela erminea L.) Z. Säugetierk., 49, 1: 57.

WOLSAN M. (2): Concerning the variation in the number shape and size of incisors in fissiped carnivores. Acta zool. cracov., 27, 6: 107-120 [Polish summ.]. WOLSAN M. (3): Dental abnormalities in the pine marten Martes martes (L.) (Carnivora, Mustelidae) from Poland. Zool. Anz., 213, 1-2: 119-127 [German summ.].

WOLSAN M. (4): The origin of extra teeth in mammals. Acta theriol., 29, 10: 128-133 [Polish summ.].

WOLSAN M. (5): Two dental anomalies in the Weasel (Mustela nivalis L.). A supernumerary premolar and a reduced upper molar (Mammalia, Carnivora, Mustelidae). Zool. Abh. Mus. Tierk. Dresden, 40, 5: 67-70 [German summ.].

WOŁK E. \& JOZEFCZAK E. [Mammals Res. Inst., P. A. Sci., 17-230 Białowieża]: Serum proteins of the free-ranging European bison. Comp. Biochem. Physiol., 79A, 4: $597-600$.

WOEOSZYN B. W. [Inst. Syst. \& Exp. Zool., P. A. Sci., Sławkowska 17, 31-016 Krakbow]: Postglacjalna historia fauny ssaków Dolnej Kaliforni - Post-glacial history of the fauna of mammals in Lower California. Spr. Pos. Kom. nauk., PAN oddz. Kraków, 26, 1-2: 173-176 [In Polish].

WOJCIK A. M. \& FEDYK S. [Mammals Res. Inst., P. A. Sci., 17-230 Białowieża]: Breeding parameters in the bank vole of different esterase phenotypes. Acta theriol., 29, 26: 305-316 [Polish summ.].

WOJCIK J. M., see MIÆKOWSKI L. \& WOJCIK J. M.

ZALEWSKA B. (1), see GROMADZKA-OSTROWSKA J. \& ZALEWSKA B.

ZALEWSKA B. (2), see JAKUBOW K. et al.

ZALEWSKA B. (3), see JAKUBOW K. et al.

ZAMO.JSKA D. [Inst. Fund. Vet. Sci., Agric. Techn. Acad., 10-957 Olsztyn-Kortowo]: Histomorfologia naczyń krwionośnych ściany rogów macicy świni w okresie fazy pęcherzykowej cyklu płciowego - Histomorphology of blood-vesstage of sexual cycle. Zesz. nauk. ART Olsztyn 247, Wet. 14: 25-33 [In Polish with English and Russ. summ.].

ZBOROWSKA E., see CZARNOMSKA A. et al. 
ZIOŁO I. [Inst. Anim. Anat., Agric. Acad., Akademicka 12, 20-934 Lublin]: Ocena przebiegu procesu mielinizacji $\mathrm{w}$ drogach nerwowych rdzeniowo-móżdżkowych u świni - A comparative estimation of myelination of the spinocerebellar tracts in the pig. Annls Univ. M. Curie-Skłodowska, DD, 35/36 (1980/81), 3: 21-32 [In Polish with English and Russ. summ.].

ZUURKOWSKI M., see TOMASZEWSKA-GUSZKIEWICZ K. \& ZURKOWSKI M.

\section{SUBJECT INDEX ${ }^{1}$}

\section{GENERAL Literature}

Pucek - 1 .

1. EVOLUTION AND GENETICS

Czarnomska et al.; Kielan-Jaworowska - 1, 2, 3; Krzanowski - 2; Sikorski \& Bernshtein; Sysa et al.; Szymura \& Klein (1982); Szymura et al. (1982); Tomaszewska-Guszkiewicz \& Zurkowski; Wójcik A. M. \& Fedyk.

\section{MORPHOLOGY}

Białowąs et al.; Boratyński, Flieger et al.; Boratyński et al.; Czarnomska et al.; Dobrowolska \& Gromadzka-Ostrowska; Dudziak et al.; Dydyk; Dyrczowa; Flieger, Boratyński et al.; Flieger, Sławomirski et al.; Flieger, Strzałka et al.; Gąsienica-Byrcyn (1983); Gienc \& Kuder; Hereć et al.; Jabłoński \& Brudnicki; Jaczewski - 2; Jastrzębski, Boratyński et al.; Jastrzębski, Flieger et al.; Klevezal et al:; Kielan-Jaworowska et al.; Knasiecka; Langenfeld (1983); Męczyński (1983 - 1, 2); Kuder - 1; Lasocka-Moskalewska; Majewska-Michalska; Mamos; Milart et al.; Nadachowski 1. 3; Nitecka et al. (1983); Rachowiak; Roskosz \& Kobryńczuk (1983); Rowiński et al.; Sikora; Sikorski \& Bernshtein; Sławomirski et al.; Strzałka \& Flieger (1983); Strzałka et al.; Szatkowska; Szteyn \& Łakomy; Szteyn et al. (1983); Welento et al.; Węgrzyn \& Makowiecka (1983); Weegrzyn et al. (1983); Węgrzyn \& Serwatka (1983); Węgrzyn \& Serwatka; Wiland \& Brudnicki; Wolsan - 1, 2, 3, 4, 5; Zamojska; Zioło.

\section{PHYSIOLOGY}

Chwedeńczuk \& Lehman-Kryszak; Daniłoś - 1, 2, 3, 4; Dobrowolska \& Gromadzka-Ostrowska; Gębczyński \& Gębczyńska; Górecki et al. (1982); Gro- dziński \& Weiner; Gromadzka-Ostrowska \& Szylarska-Góźdź; Gromadzka-Ostrowska \& Zalewska; Jabłoński \& Brudnicki; Jaczewski - 1; Jaczewski \& Bartecki; Jakubów et al.; Lewandowski (1983); Wiślińska et al.; Wołk \& Józefczak.

$$
\text { 4. REPRODUCTION, SEX, }
$$

Gromadzka-Ostrowska \& Szylarska-Góźdź; Gromadzka-Ostrowska \& Zalewska; Jaczewski - 1; Jaczewski \& Bartecki; Jakubów et al.; Korwn-Kossakowski \& Sumiński; Krzywński \& Bobek; Krzywiński et al.; Neczyński (1983 - 1, 2); Ożdżeński \& Presz; Sysa \& Kaluziński; Sysa et cl.; Smiełowski (1982); Smielowski; Wojcik A. M. \& Fedyk; Zamojska.

$$
\text { 5. DEVELOPMENT }
$$

Gębczyński \& Gębczyńska; Klevexal et al.; Korwin-Kossakowski \& Sumński; Krzywiński et al.; Wiślinśski et al.

\section{ECOLOGY, BIOLOGY}

Bobek; Bujalska \& Mieszkowsła; Chwedeńczuk \& Lehman-Kryszck; Dzięciołowski; Fedyk et al.; Gebczynska \& Raczyński; Górecki et al. (1982); Gliwicz - 1, 2; Grodziński \& Weiner; Grodziński et al.; Jaczewski - 1; Janion \& Malinowski; Jezierski \& Bruski; Jezierski \& Gebler; Kałwa \& Tomek (1983); Krzanowski - 2; Iesiński; Mazurkiewicz; Miłkowski \& Wójcik J. M.; Nabagło et al.; Okarma; Parusel - 1; Pielowski (1982); Pielowski - 2; Pucek - 2; Roma; Sikorski \& Bernshtein; Szukiel; Smiełowski (1982); Smiełowski; Tomek \& Zygarowicz (1982); Walkowa et $\imath l$. (1983); Weiner \& Górecki (1982); Weiner et al. (1982); Weiner, Grodzińssi

1 Year of publication is given after the author's name only for papers publishtd in 1982 and 1983. It is omitted where it is 1984. 
et al. (1982); Zieliński (1982 - 1); Zurowski (1983).

$$
\text { 7. DISTRIBUTION. FAUNA }
$$

AND SYSTEMATICS. PALAENTOLOGY

Bocheński (1983); Dashzeveg \& Kielan-Jaworowska; Dyrczowa; Kielan-Jaworowska (1982); Kielan-Jaworowska (1983); Kielan-Jaworowska - 1, 2, 3; Kielan-Jaworowska et al.; Kownacki; Krzanowski (1983); Krzanowski - 1; Kubiak (1982 - 1, 2); Kubik et al.; Lasota-Moskalewska; Leśniczak;

Accepted, July 29, 1985.

Mammals Research Institute, Polish Academy of Sciences, 17-230 Białowieża, Poland
Matuszewski \& Sumiński; Nadachowski - 1, 2, 3; Parusel - 2, 3; Pielowski - 1; Pucek (1982); Pucek; Romanowski et al.; Ruprecht; Sikora (1983); Woloszyn.

\section{PARASITES, EPIDEMIOLOGY} AND PATHOLOGY

Haitlinger - 1, 2, 3; Kozakiewicz \& Maszewska; Romaniuk et al. (1983); Samól \& Borowiecki; Wegner \& Kruminis-Łozowska. 